\title{
Practical Aspect of Newar Buddhism and the Context of History
}

\author{
Dr. Nivedita K. Mishra*
}

\section{Introduction}

Buddhism of Nepal is popularly known as Newar Buddhism. It denotes to the Mahayana and Vajrayana Buddhist tradition widely practiced by the Newar community in Nepal. Newar Buddhism itself is the outcome of the spiritual endeavour of Buddhist mission started right since its inception. In the process of propagation in forthcoming centuries, Sri Lanka became the centre of Sthaviravada (Hinyana) whereas Mahayana got its roots in the countries located north of India. ${ }^{1}$

The curious admixture of the doctrine of Mahayana including Vajrayana, and the worship of Hindu deities especially those forms to which later tantras are devoted, are the subjects of attraction. It attracted many historians and philosophers to ponder over it. The spirit of polytheism has always been an accommodating one. The trend that legends of one community or religious sect are readily adapted by the other, but it is difficult to assign them to their original sources ${ }^{2}$. Thus, adoption of tenets become more natural.

However, the presence of Buddhist monuments, which closely resemble with ancient Indian Stupas confirm that Buddhism had already entered into the Kathmandu Valley around the beginning of Christian era ${ }^{3}$. Mahayana Buddhism continued flourishing and expanding along with the Vajrayana tradition up to the $12^{\text {th }}$ century. ${ }^{4}$ By this time, Vajrayana tantra became very popular in the Buddhist society. In fact, tantra came to Nepal from their sources in the plains of India. ${ }^{5}$

Newar Buddhism is primarily a ritual Buddhism. Ritual performance is a part of Tantric practice in Vajrayana tradition. Those practices are based on ritual texts.

\section{The Newar Buddhists of Kathmandu Valley}

The Newar community of Kathmandu Valley is mainly divided into two groups Buddhists and the Shaivite. The Buddhist Newars consist of two groups - the

* Dr. Nivedita Kumari Mishra is a Lecturer in the Central Department of Sanskrit and visiting Lecturer at the Department of Buddhism, Tribhuvan University, Kirtipur, Kathmandu, Nepal.

1. David L. Snellgrove, Buddhist Himalaya, Oxford: Bruwardcassiser, 1957, p. 94; Siegfried Lienhard, The World of Buddhism, Buddhist Monks and Nuns in Society and Culture, New York: Facts on File Publication, 1984, p. 109.

2. Edwin T. Atkinson, Himalayan Gazetter, Vol. II, New Delhi: Cosmo Publication, 1973, p.764.

3. Snellgrove, f.n.no.1, p. 94; W.B. Doughlas, Literary Sources of Gunakaranda Vyuha Sutra, (a paper presented at the seminar organised by the Lotus Research Centre), Kathmandu: 1998, p.1.

4. The earliest reference of the term Vajrayana in Nepal is found in Amshuvarma's Gokarna inscription. Dhanvajra Vajracharya, Licchavi Kalka Abhilekha, Kathmandu: INAS, 2030 B.S., p.370.

5. Atkinson, f. n. no. 2, p. 764. 
upasaka and the Bare. The term Bare denotes to the highly reverend group of Newar Buddhists. They are also called Bandya, which is a term of respect. ${ }^{6}$ The term Bandya is derived from Sanskrit word Bhadanta. Its Pali equivalent is Bhante, the reverend one.

The Bare community is comprised mainly of Vajracharyas and Shakyas, the two prominent groups of Buddhist Newars in the Kathmandu Valley. Both the groups are considered as monks because they obtain monastic initiation and traditionally accept alms from the Kings ${ }^{7}$. Similarly, they also receive Dana at Samyaka and Panchadana festivals. ${ }^{8}$ During the process of monastic initiation, some questions are asked by the priests to the neophytes, which are worthy of mentioning. Those questions are based on the verifying process whether the candidate wants to go forth for further initiation or live the life of a householder. ${ }^{9}$ If he wants to change his mind of becoming a monk, he is allowed to do so. In the case to continue the monastic life, the incumbent again requests to give him further Pravrajya Vrata. ${ }^{10}$ The Shakyas are lay Buddhist monks who mostly follow the rituals as prescribed by Adikarmapradipa. The rituals are directed to the disciples to be observed. ${ }^{11}$ Moreover, some of the Shakyas and Vajracharyas are also initiated in Hevajra tantra. Initiation in Hevajra tantra requires a long preceding initiations in various disciplines. For an instance, aspirant of Hevajra initiation must have to observe posadha and learn Siksapada in the beginning and so on. ${ }^{12}$ Moreover, after monastic initiation the Bare usually take Bodhisattva vows. It is the basis to take refuge in the Three Jewels and observe the five precepts. During the process to observe Boddhisattva practice they recite and study Nava Granthas (the nine

6. John K. Locke, Karunamaya, Kathmandu: Sahayogi/CNAS,1980, p.10.

7. D.N. Gellner, Monks, Householder and Tantric Priests, Cambridge: Cambridge University Press, 1992, p.162. There is a controversy among the scholars whether the Bares are monks or not. Although anthropologists may accept them as monks, historians and experts of religion do not agree on it. Since, they abandon the life of a monastic at the end of initiation ritual, they merely remain as householders.

8. C. Rosser, 'Social Mobility in the Newar Caste System', in C.Von Fuher Haimendorf (ed.), Caste and Kin in Nepal, India and Ceylon, Bombay : Asia Publishing House, 1966, p. 128.

9. cBflkTj+ u[XLOff+, ;dfgd]j Is+ kljHofof+ IgZroOlt . olb aljLIt IgZro Olt - Badri Ratna Vajracharya, Chudakarma Vidhana, Kathmandu: Bajracharya Samrakshan Guthi, 2030 B.S., p.29. Also see: Min Bahadur Shakya, 'A Historical Analysis of Monasticism in Newar Buddhism', Voice of History, Vol. XV, No.1, June 2000, p.74.

10. cxldTy+gfdf ofjHhLj+ u[xLInË+ kl/ToHofld kljHoflnËdfbj] . Vajracharya, f.n.no.9, p.6; Shakya, f. n. no. 9, p.74.

11. $\mathrm{k} \mid 0 f D o>L$ u'?gleSt of lhgfg -r_;'tfg cy cflbsd\{k|bLkf] odl tbfly\{Eof] ljiwot]

IziofOff+d cfz' af]wfy\{dl InVot] :kw\{of $r$. L.V. Pussin (ed.), Adikarma Pradipa, Brussels: Etude Et. Maderiaus, mamor de i' Academic de E. Belgiqve, p. 186.

12. "Posadam diyate Prathama Tadanu Siksapadam diset, Baibhasyam tatra deseta sutrantam bai punastatha,Yogacaramtat Diseta Tadanu Madhymakam Diset, Sarvamantranayam Gnyatva Tadanu Hevajra Marabhet". G.W. Farrow and I. Menon, Hevajra Tantra, Delhi : Moti Lal Banarsi Das, 1992, p. 273. 
Mahayana Sutras). After generating aspiring bodhichitta, they follow the ten Bhumis cultivating one of the Paramitas in each Bhumi leading to the realization of Sunyata and develop the quality of Yathabhuta Jnana. The Bhumis and Paramitas are not cultivated by the Newar practitioners although it is prescribed in Buddhist scriptures. It should be noted that Newar Buddhism is a ritual Buddhism. As a matter of fact, Philosophical ideas are not important for them to know because those ideas are transformed into ritual patterns.

The second group of Buddhists are the upasakas, the followers. They perform rituals with the support of Vajracharya priests .

\section{The Context of History}

Historical references are found in the form of inscriptions that deal with different aspects of Nepalese Buddhism. The inscriptions found in Sankhu, Hadigaon and Gokarna are very important to shed light on history of Nepalese Buddhism. Those are the oldest recorded history of Buddhism in Nepal. ${ }^{13}$ The Lichhavi period marked speedy growth of Nepalese Buddhism. They are said to have migrated to Nepal from Vaisali. ${ }^{14}$ The Lichhavi rulers patronized Buddhism and provided a base to flourish it in Nepal.

The intolerant and indifferent attitudes of Sung and Satvahana dynasties in India ${ }^{15}$ and imperialistic design of Kusana rulers might have compelled Licchavi rulers as well as other Buddhist monks to flee to Nepal. Vaisali was an active centre of Buddhism during the life time of Gautam Buddha. ${ }^{16}$ The 'Arthashastra' of Kautilya (4th century B.C.) refers Nepal as a trade route to Tibet. ${ }^{17}$ Though, further description about it is not available in the text, but several classical Buddhist texts also mention its existence.It may be possible that the Licchavis and other Buddhist monks proceeded towards Nepal which was on the route from Patliputra to China.

According to the Chinese tradition, several monks went to China in order to propagate the Dharma. The Chinese classical scriptures as well as some Indian sources record that Indian as well as Nepalese monks visited China in the ancient times. Ven. Ci-Li- Fung along with eighteen other monks appeared in the Royal Court of China in the 3rd century B.C. carrying some Buddhist scriptures. ${ }^{18}$ Regarding Buddhists' migration to Nepal, history has proved that certainly they migrated to Kathmandu from Magadha during the rule of Sungas in India.

13. Vajracharya, f.n.no.4, pp. 320, 370, 450 and 507-508.

14. R.N. Soletore, Encyclopaedia of Indian Culture, Vol. III, New Delhi : Sterling Publishers, 1983, p.841.

15. Ramshankar Tripathi, Prachin Bharat Ka Itihas, Delhi : Motilal Banarsi Das, 1962, p. 162.

16. Soltore, f.n. no.14, p. 840.

17. æci6Knf]lt +3ft s[iOff lela ${ }^{\mathrm{a}}$;L jif $\{$ jf/Of dk;f/s Olt g\}]kfnsdl.ÆE G.Sastri (ed.), Kautilya Arthasastra, Delhi : Bhartiya Vidya Prakashan, 1990, p.193.

18. Damodar Singhal, Asiamey Baudh Dharma, Meerut : Minakshi Prakashna, 1992, p. 37. 
In fact, Buddhism did not get proper attention from the royalty in India. It was rather treated disdainfully. ${ }^{19}$ Historical sources mention that right from the time of the second Buddhist council (380 B.C.) till the arrival of Chinese traveller I - tshing (671 A.D.), Magadha was the centre of Mahasanghika monks. ${ }^{20}$

In the early history of Buddhism, Vaisali is described as a town crowded with non-Buddhist thinkers, and as a centre of the followers of Nigantu Nathaputta. Hence, non- orthodox Buddhists should find footing there. ${ }^{21}$ The inference of existence of the followers of Mahasanghika in Vaisali around 300 B.C. can be agreeable to some extent. Similarly, Magadha including Patliputra seems to have resided by the Mahasanghika monks. Later, they migrated to other places. There is the possibility of migration of Mahasanghika monks along with the Licchavis to Nepal during that time. One of the causes of their migration to Nepal may be the strength of Brahmanism, which compelled them to find out favourable environment to propagate the Dhamma in this part of the continent. Nepal may be placed among one of those safe passages. Availability of coins of Kadiphus I and II in Nepal convinces, to some extent, that some kind of linkage either of trade relations or transmigration of monks existed between the Kusana empire and Nepal.

It has already been proved that migration of Buddhist monks started with the emergence of Mahasanghika and Sthavira sects. In the beginning around 300 B.C., Mahasanghika monks went both to the north and the south. They were active till the reign of Huviska (100 A.D.), the successor of King Kanishka. ${ }^{22}$ During the reign of Kanishka, Sarvastivada was the dominant faith in India. Theravada and Sarvastivada remained important during the days of Asoka and Kanishka. ${ }^{23}$ Hence, it may be possible that existing environment might have compelled them to move towards safer places. During that time, presence of Mahayana in the valley of Kathmandu can be considered as a ground for such an assumption. ${ }^{24}$ Until 100 A.D., Mahayana flourshed in the Kathmandu Valley with the support of Mahasanghika monks. In this context, it should be noted that Mahayana evolved in South India where Chaityavadi offshoot of Mahasanghika sect existed. In Mahavastu, which is an avowed text of Lokottaravada, the worship of Chaitya is given prominence. ${ }^{25}$

It is noteworthy that Newar Buddhist pactitioners are very close to the philosophical aspect of Chaityavada, a branch of Mahasanghika sect. ${ }^{26}$ Thus, it is assumed that the northern Mahasanghika monks along with southern Chaityavadi

\footnotetext{
19. Tripathi, f. n. no. 15, p.143.

20. Nalinaksha Dutt, Buddhist Sects in India, Delhi: Motilal Banarsi Das, 1978, p.61.

21. Ibid., p.9.

22. Epigraphica Indica, Vol. XI, New Delhi: Archeological Survey of India, 1981, p.211.

23. Ankul Chandra Banerjee, Sarvastivada Literature, Calcutta : The World Press, 1979, p.5.

24. D.R. Regmi, Ancient Nepal, Calcutta : K.L. Mukhopadhyaya, 1960, p.70.

25. Dutt, f. n. no. 20, p.57.

26. Nivedita Kumari Mishra, 'Vajrayana in the Context of Nepal', (Ph.D. dissertation submitted to Patna University, 2000), pp. 94-111.
} 
monks accelerated the flow of Mahayana in the Kathmandu Valley from $1^{\text {st }}$ century to the $8^{\text {th }}$ century A.D. ${ }^{27}$

27. Ibid., pp. 76-82. 


\section{The Account of Fa-Hi-Yan.}

Fa-Hi-Yan (399-417 A.D.), a Chinese traveller wrote in his travelogue that people of Magadha were enthusiastic in giving donations. They were very pious and particular in matters of religious duty. On the eighth day of second month every year, they used to cerebrate chariot festival carrying the images of Buddha and Bodhisattvas. $^{28}$

John Locke is of the opinion that the festival of Lokesvara started in the Kathmandu Valley in the seventh century during the reign of Narendra Dev. ${ }^{29}$ Still Lokesvara is supposed to be the guardian deity of the Buddhist Sangha in the Kathmandu Valley. Monastic ritual has been observed for him in the form of Uposatha fasting. Another remarkable feature related to Lokesvara is that the neophytes salute considering him as the Sangha along with the Buddha and the Dharma as part of Pravajjya ritual. The tradition of chariot festival was developed by the Mahasanghika monks. During the $7^{\text {th }}$ century Lokesvara festival was introduced in Kathmandu. Thus, it is confirmed so far that right from the fifth century up to the seventh century Mahasanghikas were famous in Magadha ${ }^{30}$ as well as in Kathmandu. Transmigration of those monks to the Kathmandu Valley obviously introduced the cult of Lokesvara.

\section{Aspects of Newar Buddhism}

\section{The Parivrajaka.}

The terms Bhikshu and Parivrajaka are used in English and Sanskrit to denote asceticism. The Newar Bare should be distinguished in terms of Sanskrit word Parivrajaka in spite of calling them the monks.$^{31}$ The Sanskrit term Parivrajaka is derived from the root Vraj (to go) prefixed with Pari which denotes to going around. ${ }^{32}$ Again the term 'monk' is derived from the Greek words monachos and monos which means secluded or alone. ${ }^{33}$ The word lays emphasis on isolated living and detachment from the worldly society. This solitude must not however be interpreted as implying absolute isolation such as that of a hermit in a desert. Moreover, it is the life within the monk community in which they are indeed separated from the world but not from one another. ${ }^{34}$

28. Samual, Beal, Travel of Fa-Hi-Yan: Buddhist Records of Western World, New Delhi : Sushil Gupta,1964. pp 23-40.

29. Locke, f. n. no. 6.

30. Thomas Watters, Yuan Chwang's Travels in India, Delhi : Munshi Ram Manohar Lal, 1961, p. 26.

31. Mishra, f. n. no. 26, p.29.

32. Monier Williams, Sanskrit- English Dictionary, New Delhi: Motilal Banarsi Das, 1990, p. 389.

33 Shanker Thapa, Buddhist Monasticism in Theory and Practice, Kathmandu: Walden Books, 1995, pp.11-25.

34. James Hastings (ed.), Encyclopaefdia of Religion and Ethics, Vol. 8, Edinburg: T \& T Clark, p. 781. 
The term Parivrajaka is also used to denote mendicants who abandon the world and go forth in search of liberation. ${ }^{35}$ But the root verb Vraj denotes to strenuous efforts for finding the ultimate truth. It further reveals the notion of a kind of movement where as the word monk gives impression of detachment or renouncement.

Due to the prevailing features, the Newar Bare, as a matter of fact, are closer to the concept of Parivrajaka. The goal of attaining liberation and active craving for the same is found in them in abundance. They are not attached to the western concept of the term monk. In the Bare community, a novice is given Pravrajya initiation, which is a ritual to enter into the Bhikshu Sangha.

In ancient times, if someone wanted to follow the vows of Buddhism the incumbent used to request the Sangha to initiate him as a Bhikshu. ${ }^{36}$ Having been accepted, he started to practice the vows of disciplines.

It is said that Pravrajya, taken so far in the sense of renouncing the worldly desires is the symbolic practice of cutting all obstacles in the path of attaining the ultimate truth. ${ }^{37}$ Upasampada is the ordination, which declares complete detachment of the household life thereby going refuge in the Sangha. In the Newar Buddhist society, Upasampada (higher ordination) is not given to the neophytes. Only after certain period of probation, ${ }^{38}$ a neophyte may be given full ordination. Without having this ordination, they remain only the ascetic practitioners but not fully detached from the household bindings. ${ }^{39}$ The absence of upasampada in Newar society obviously proves that they are a kind of ascetic practitioners. Their religious behaviour established them as the Buddhist parivrajka. They are bound to follow discipline and observe rituals. They also need to inspire the upasaka to do so.

\section{The Mahasanghika Sangha in Kathmandu}

It is well stated in different scholarly writings how wandering ascetics were grouped under various sects and sub-sects in the ancient times. ${ }^{40}$ It was very simple in the beginning to take refuge in the Buddhist Sangha as a monk. ${ }^{41}$ But gradually various rules and regulations were introduced. ${ }^{42}$ After the second Buddhist council in 400 B.C. different Buddhist sects were created. ${ }^{43}$ The sectoral division had not taken place in a short span of time. In fact, ideological differences and the impact of surrounding social and religious environment led to the division among the Buddhist monks. It finally

35. Taranath, Vachaspatyam Panchamo Bhaga, Varanasi: Chaukhamba Sanskrit Series, 1962, p. 4257. Also see : Thapa, f. n. no. 33, pp. 1-3.

36. Madan Mohan Singh, Bouddhakal Mein Samaj Evam Dharma, Delhi : Delhi University Press, 1993, p.68.

37. æ,;jf\{j/Of ljzf]wg] ,;j\{1fgfj/OfR5]bo x'+:jfxf.ÆE Bajracharya, f. n. no. 9, p.5.

38. Foushall (ed.), Jataka Katha, London: Trubner and Co., 1877, p. 106., Quoted in Singh, f. n. no. 36, p. 166.

39. Shakya, f. n. no.9.p. 66.

40. Sukumar Dutt, Early Buddhist Monachism, Delhi: Motilal Banarsi Das, 1920, p. 11.

41. For detail see : Singh, f.n.no.36, p.63.

42. Sukumar Dutt, Buddhist Monks and Monasteries, Delhi : Motilal Banarsi Das, 1988,p.68. 
resulted in creation of different sects. By the time of Emperor Asoka, eighteen Buddhist sects came into existence. It is said that Sthavira and Mahasanghika are the pioneer of the sectarian development but there are also varied opinions. ${ }^{44}$ The history of Newar Buddhists and their religion goes back to 200 B.C. The existence of Buddhist Monastic in the Kathmandu Valley is possible from that period. ${ }^{45}$

Before dealing with philosophical outlook and observances of the Bares identical with Mahasanghika approaches, the historical presence of Mahasanghika in the Kathmandu Valley needs some attention. The Licchavi inscriptions throw light on the presence of Mahasanghikas in the Kathmandu Valley. ${ }^{46}$ The Musumbahal inscription of Narendra Deva mentions the presence of a Bhikshuni Sangha probably belonged to the Mahasanghika sect. ${ }^{47}$ An inscription of Amsuvarma also mentions about the Mahasanghika Bhikshuni Sangha. ${ }^{48}$ Furthermore, an inscription is excavated in Bhaktapur so far which also mentions about the presence of Mahasanghika Bhikshani Sangha there. ${ }^{49}$ The existence of Mahasanghika Sangha in Nepal can be assumed by the names of Vihara mentioned in the Pashupati and Yagabahal inscriptions of Narendra Deva. The inscriptions mention Shivadeva Vihara, Kharjurika Vihara, and Yangu baha. Shivadeva's inscriptions also mention the Viharas such as Manadeva, Khajurika, Madhyama, Abhayaruchi and Kalyanagupta Vihara. ${ }^{50}$ The term Aryasangha is also found in those inscriptions. ${ }^{51}$

As Sukumar Dutt describes, the term Chaturdisha Arya Bhikshu Sangha is the ideal concept of old monastic settlement. The Aryasangha is meant a body of resident monks in a monastery. ${ }^{52}$ The word Sangha represents to the body of a monastery and the residing monks. ${ }^{53}$ One more remarkable point related to Aryasangha is that donations were given for the worship of Lokesvara. ${ }^{54}$

43. Dutt,f.n.no.20, p.14.

44. Rahul Sankrityayan, Buddha Darshan, Allahabad : Kitab Mahal, 1992, pp. 55-56.

45. K. P. Chattopadhyaya, An Essay on the History of Newar Culture, Kathmandu : Educational Enterprises, 1980, p.9. Also see: Snellgrove, f.n. no.1, p.94.

46. The inscription of Sankhu mentions, ;f+|3s lelf' ;+3:o=ニニ=ニ, Vajracharya, $\mathrm{f} . \mathrm{n}$. no. 4, p. 508.

47 t:o ;+:sf/ k"hfy\{dl lelf'OfL ;+3 ;dlk\{tf kOfM k'/fOf, ;Ixtf k|]sNkot।tt .

48. dxfofg k|lt kGgfy\{ lelf'OfL ;+3 kl/ef]ufoflfoOfLjL k|ltkflbtf==. Ibid., p.382. Vajracharya, f. n. no. 4, p. 382.

49. Pasuka, Vol. II, No. 11, N.S. 1118.

50. Hem Raj Shakya, Buddha Murti Chhagu Adhyayan, Kathmandu :Khwaspusa, 1091 N.S., pp.3-4.

51. a'wf] ej]t। If]q r e"ld !) eujtf]:ofjnf]|st]Zj/:o w"k bLkg] df cfo\{3:o $r$ df. E Vajracharya, f. n. no. 4, p. 386.

52. Dutt, f. n .no. 40, p.69.

53. Ibid., p. 69.

54. Vajracharya, f.n.no.4, p. 386, and Vajracharya, f. n. no. 9, p.14. The term 'Arya Sangha' is repeatedly pronounced in the proceedings of Pravrajya ceremony. 


\section{Concepts and Practices}

The Mahasanghikas who used to live in Dhanyakataka area was called Chaityavadi. Mahavastu ${ }^{55}$ and Sikshyasamuccaya ${ }^{56}$ describe about Stupa and its worship. Hence, the Chaitya Puja became popular among the laity.

At the time of Pravajya initiation, a novice monk requires to worship a Chaitya ${ }^{57}$ This practice does not exist in Theravada tradition. Similarly, a Silaku (the staff), which a novice holds, has an impression of Chaitya on the top. Almost in every Vihara either inside the shrine or at the entrance, two images are often seen standing holding staffs engraved with Chaitya impressions.

Several Bodhisttvas are described in the Buddhist texts. Among them Sri Khara Lokesvara and Sri Khikhara Lokesvara are prominent. Lokesvara is supposed to be the monastic deity. These Lokesvaras hold staffs with Chaitya impressions.

Many Shakyas and Vajracharyas in the Kathmandu Valley worship enshrined Chaitya, at Vajrayogini, as the lineage deity. The Sangha of Kwabaha in Patan worship Svayambhu Chaitya as the lineage deity. When they worship Chaitya, no blood sacrifice is ever made. ${ }^{58}$

In fact, offering worship and erecting Chaityas during tantric observances, the tradition of venerating Chaityas, presence of numerous votive Chaityas in Buddhist shrines remind the doctrine specially attributed to the Chaityavadi sect. One can obtain merit by creation, decoration and worship of Chaityas. Even a circumbulation of Chaitya accumulates merit. Similarly, offering of flowers, garlands and scents to the Chaityas are likewise meritorious. ${ }^{59}$ Furthermore, Cailaka Shakyas are initiated before the Chaitya instead of initiated in monasteries.

\section{Practice of Dana}

The perfection of donation(danaparamita), which is one among six perfections, lays emphasis on Bodhisattva practice of giving donations.In the Kathmandu Valley, Shakyas and Vajracharyas are the recipient of Dana but at the sometime they also offer dana to other recipients during Samyak and Panchadana festivals. The views of the Chaityavadi sect regarding the practice have certain similarities with the practices of the Bares. In fact, both the Bares and ancient Chaityavadis desired happiness in both the worlds for themselves and for the entire sentient beings. An inscription in Nagarjunikonda elaborates the conceptual orientation of the Chaityavadis. ${ }^{60}$ Similarly, the word Mahasanghika is repeatedly uttered in verses recited at the time of offering

55. E. Senart (ed.), Mahavastu, Vol. II, Paris, 1882-1897, p. 362.

56. Shantideva, Sikshyasamuccaya, Darbhanga Mithila Institute, 1961, p.156. Also see: B. Bhattacharya (ed.), Nispannayogavali, Baroda: Oriental Insitute 1972, pp.54-65.

57. Vajracharya, f. n. no.9, p.14.

58. Gellner, f. n. no. 7, p.241.

59. P.V.Bapat, 2500 Years of Buddhism, New Delhi: Ministry of Information and Broadcasting, 1997, p.104.

60. ...peo nf]s Ixt ;'vjxgfoú is mentioned in Nagarjunikonda inscription which is attributed to the Chaityavadi sect, Dutt, f. n. no. 20, p.116. s|dfT;'a\{z] kl/jf/ o'Stf:t] lbJonf]s] Wod[t neGt] .ÆE 
donations to Dipankara Buddhas. ${ }^{61}$ The Danagatha is recited at those ceremonies is extracted from Mahavastu.

There is a practice among the Newar Buddhists to handover ornaments to a novice. A candidate of Pravajya ceremony is presented with two silver bracelets, a pair of earrings, a silver necklace along with robes, begging bowls, a staff and a ritual umbrella. The practice of giving ornaments to a novice or a Bhikshu is a similar practice mentioned in the Bodhisattvapitaka. As mentioned in the text, ornaments are offered to the Mahasattva who belongs to Mahasanghika. ${ }^{62}$ The Pravajya ritual observed by the Newar Bare still have remnants of the influence of Mahasanghika doctrine to some extent. There is a tradition that a Newar novice has to make request in front of the elders of the Sangha to initiate him as a Parivrajaka and utter Buddhatvapada Praptaye 63 (In order to aquire the position of the Buddha). The aim of Pravajya initiation is to go-forth in the path of enlightenment, thereafter acquiring Buddhahood. It was also the core doctrinal approach of the Mahasanghika sect.

\section{Abandoning Celibacy}

Newar Buddhist practice is obviously the Vajrayana tantric practice. They are very much concerned with ritual aspect of tantra rather than its philosophical understanding. They also have to follow certain rules and observances as followed by the ancient monks. The Pravajya initiation is a ritual to renounce the worldly desire, but at the end of the ritual a Newar Parivajaka observes Chivarkote rite to abandon the life of a homeless. How and when this ritual practice was introduced in Newar Buddhism is yet not known, but its significance is that it lays emphasis on householders' life instead to continue the practice of celibate monasticism. Even in such a situation, the Bares claim that they are the monks. It is mentioned earlier that a Newar does not take higher ordination (upasatha) because this tradition has already been died out. However, the Buddhist householders, could observe Bodhisattva vows. $^{65}$

The Bares themselves are of opinion that the ritual of disrobing does not signify abandoning monastic vows but the transition from Sravakayana to Mahayana practices. ${ }^{66}$ The evidence of married monks is also found in ancient texts such as Kalhan's Rajtarangini. ${ }^{67}$ Above all the most important cause behind indifferent attitude

61. æof] ;f\}+utfKo\{, ;'uftf]dl ;flks]Do:t] k|fKg'jlGt ;'//fh dx]Gb| nldL .æ Birendra Muni Vajracharya (ed.), Aum Namah Sri Depankara Buddhaya Dan Gatha, Kathmandu, Birendra Muni Bajracharya, Kathmandu: n. d, p. 15, Verse nos. 6,7,8,14 and 17 refer the word Sanghika.

62. Bodhisattva Pitaka, National Archives, Kathmandu: Folio No. 106/327, p.2.

63. Vajracharya, f.n.no.10, p. 1.

64. Dutt, f.n.no.20, pp.71-76.

65. Vajracharya, f. n. no. 10, p. 21. hutf]|xtfo s'ofdh,+| ;'v,+lxtfo cBf/De k|aHof InËdgtfo\{ k'gu[\{xL InË bfjf s'nwd\{ k|a]zo:j .

66. Shakya, f.n.no.10, pp. 68-72.

67. Garhasthyagarhyah is the word which is used for the married monks. M. A. Stein, Kalhana's Rajtarangini: A Chronicle of the Kings of Kashmir, Vol. I, Delhi: Motilal Banarsi Das, 1961, p.74. 
of the Newar practitioners is the impact of tantric tradition. ${ }^{68}$ Sikshasamuccaya also mentions householder monks and their engagement in household duties. ${ }^{69}$ It also has been assumed that the Mahasanghika have influence on Vajrayana dogmas, tenets, rites and practices.

\section{Conclusion}

The historical context and Buddhist practices of Newar Buddhist practitioners point towards their relations with the ancient Mahasanghika. During the process of development of Vajrayana, conceivable tenets, dogmas, rites and practices were included in this school. Benoytosh Bhattacharya writes the leading tenents of Mantrayana along with mantras, Mandalas, Mudras and Gods and Goddesses were included in Vajrayana. The earliest work of this class is said to be the Vidyadharapitaka which has been characterized by Huen-Tsang as belonging to the canonical literature of the Mahasanghikas. ${ }^{70}$

Thus it can be assumed to some extent that Mahasanghikas were more or less responsible for introducing tantric practices. Those practices were handed down through successive chains of preceptors and discipline. Again married status of the Bares is questioned frequently. The tantric Vajrayana follow the path which incorporates Prajna and Upaya which are symbolized by female and male forces respectively. So, the tantric process proceeds in the way of emancipation with having consort and full-fledged householder state. Hence, the Bares are married.

Finally, it seems proper to present the view that Buddhism entered in the Kathmandu Valley in earlier flexible form. Mahasanghika sect paved the way for Mahayana and nourished tantric practices in Vajrayana Buddhism.

68. cflb a'4 dxft+q] k|oTg]g Igif]lwtM u'?dfh k|1fleif]s]:t' gu|xof a|Dxrfl/Off . Bodhipathapradipa, Sarnath: Bhot Bhavatiya Granthamala, n. d., p.65.

69. Santideva, f. n. no. 56, p.38, It mentions "k'g/k/+ s'nk'q eljioGTgfut]sWjgLu[x:yk|j|lhtf cflbsld\{sf jf]lw;Tjf .

70. Benoytosh Bhattacharya, Indian Buddhist Iconography, Calcutta: K. L. Mukhopahdyaya, 1968, p.14. Also see, Benoytosh Bhattacharya, An Introduction to Buddhist Esoterism, Delhi: Motilal Banarsi Das, 1980, p. 24 and Locke, f. n. no. 6, p. 67. 